\title{
Absence of SCAPER causes male infertility in humans and Drosophila by modulating microtubule dynamics during meiosis
}

\author{
Ohad Wormser, ${ }^{1}$ Ygal Levy, ${ }^{2}$ Anna Bakhrat, ${ }^{2}$ Silvia Bonaccorsi, ${ }^{3}$ Lucia Graziadio, ${ }^{3}$ \\ Maurizio Gatti, ${ }^{3,4}$ Ali AbuMadigham, ${ }^{5,6}$ Richard J McKenney, ${ }^{7}$ Kyoko Okada, ${ }^{7}$ \\ Saad El Riati, ${ }^{8}$ Iris Har-Vardi, ${ }^{6,9}$ Mahmoud Huleihel, ${ }^{5,6}$ Eliahu Levitas, ${ }^{6,9}$ Ohad S Birk, ${ }^{1,10}$ \\ Uri Abdu (iD ${ }^{2}$
}

For numbered affiliations see end of article.

\section{Correspondence to}

Professor Uri Abdu, Department of Life Sciences, Ben-Gurion University of the Negev, BeerSheva 84105, Israel; abdu@bgu.ac.il and Professor Ohad S Birk, Genetics Institute, Soroka Medical Center, BenGurion University of the Negev, Beer-Sheva 84101, Israel; obirk@bgu.ac.il

$\mathrm{OW}$ and $\mathrm{YL}$ contributed equally. EL, OSB and UA contributed equally.

$\mathrm{OW}$ and $\mathrm{YL}$ are joint first authors.

$E L, O S B$ and $U A$ are joint senior authors.

Received 23 February 2020 Revised 22 April 2020 Accepted 25 April 2020

Check for updates

(c) Author(s) (or their employer(s)) 2020. No commercial re-use. See rights and permissions. Published by BMJ.

To cite: Wormser $\mathrm{O}$, Levy $\mathrm{Y}$, Bakhrat A, et al. J Med Genet Epub ahead of print: [please include Day Month Year]. doi:10.1136/

jmedgenet-2020-106946

\section{ABSTRACT}

Background Mutation in S-phase cyclin A-associated protein rin the endoplasmic reticulum (SCAPER) have been found across ethnicities and have been shown to cause variable penetrance of an array of pathological traits, including intellectual disability, retinitis pigmentosa and ciliopathies.

Methods Human clinical phenotyping, surgical testicular sperm extraction and testicular tissue staining. Generation and analysis of short spindle 3 (ssp3) (SCAPER orthologue) Drosophila CAS9-knockout lines. In vitro microtubule (MT) binding assayed by total internal reflection fluorescence microscopy.

Results We show that patients homozygous for a SCAPER mutation lack SCAPER expression in spermatogonia (SPG) and are azoospermic due to early defects in spermatogenesis, leading to the complete absence of meiotic cells. Interestingly, Drosophila null mutants for the ubiquitously expressed ssp3 gene are viable and female fertile but male sterile. We further show that male sterility in ssp3 null mutants is due to failure in both chromosome segregation and cytokinesis. In cells undergoing male meiosis, the MTs emanating from the centrosomes do not appear to interact properly with the chromosomes, which remain dispersed within dividing spermatocytes (SPCs). In addition, mutant SPCs are unable to assemble a normal central spindle and undergo cytokinesis. Consistent with these results, an in vitro assay demonstrated that both SCAPER and Ssp3 directly bind MTs.

Conclusions Our results show that SCAPER null mutations block the entry into meiosis of $\mathrm{SPG}$, causing azoospermia. Null mutations in $s s p 3$ specifically disrupt MT dynamics during male meiosis, leading to sterility. Moreover, both SCAPER and Ssp3 bind MTs in vitro. These results raise the intriguing possibility of a common feature between human and Drosophila meiosis.

\section{INTRODUCTION}

It has been recently demonstrated that biallelic mutations in S-phase cyclin A-associated protein residing in the endoplasmic reticulum (SCAPER) cause an array of human phenotypes. ${ }^{1-5}$ To date, 18 deleterious variants in SCAPER have been described in a few dozen individuals from various ethnicities (South Asian, Caucasian, Amish and other Americans, Bedouin, Arab, Spanish, Iranians and others). ${ }^{1-8} \mathrm{~A}$ wide spectrum and penetrance of disease-associated phenotypes have been described, from isolated retinitis pigmentosa, developmental delay and mild/moderate intellectual disability, to brachydactyly, short stature and overweight. ${ }^{1-8}$ We have recently demonstrated that a null mutation in SCAPER causes a ciliopathy syndrome with clinical manifestations of Bardet-Biedl syndrome (BBS) as well as effects on ciliary elongation. ${ }^{3}$

SCAPER is expressed in normal human testes, is localised primarily to the endoplasmic reticulum (ER) and interacts with cyclin $\mathrm{A} / \mathrm{Cdk} 2 .^{9}$ We have recently shown that both wild-type and mutant SCAPER are expressed in primary cilia and colocalise with bundled microtubules (MTs). ${ }^{3}$ Notably, human fibroblasts from patients with homozygous SCAPER mutations displayed longer cilia compared with controls. ${ }^{3}$ In addition, the fly orthologue of SCAPER, short spindle 3 (ssp3), is required for proper spindle assembly. On downregulation of ssp3, S2 cells displayed short spindles..$^{10}$ Moreover, GFP-tagged Ssp3 was clearly associated with the spindle MTs. Thus, Ssp3 is a MT-associated protein that regulates spindle formation in S2 cells. ${ }^{10}$

Here we show that SCAPER is essential for maturation of spermatogonial cells and that a null mutation in SCAPER causes azoospermia due to an early germ cell maturation defect not related to cilia. We also show that null mutations in Drosophila $s s p 3$, which is expressed in most fly tissues, do not affect viability and female fertility but specifically disrupt male fertility. Cytological analysis revealed that in ssp3 mutant testis MT behaviour is highly abnormal, leading to severe meiotic defects in most dividing spermatocytes (SPCs). Thus, we demonstrate an essential role of SCAPER/Ssp3 in spermatogenesis in both humans and flies, suggesting that this protein regulates MT behaviour during both human and Drosophila meiosis.

\section{METHODS}

\section{Bioinformatic analysis}

SCAPER orthologues were identified using Ensembl (http://asia.ensembl.org/Gene:SCAPERENSG00 000140386) and GeneCards (https://www.genecards.org $/$ cgi-bin $/$ carddisp.pl ? gene $=$ SCAPER\# 
orthologs). Motifs shared by the orthologues were identified using MotifFinder (https://www.genome.jp/tools/motif/) analysing Pfam and COG (NCBI-CDD) databases; an E-value score of below 1e-9 was used (except Caenorhabditis elegans orthologue, for which a lower E-value of 0.00001 was used). Modelling of protein motifs was done using PROSITE (https:// prosite.expasy.org), demonstrating the suggested domains' location and range. Clustal Omega (https://www.ebi.ac.uk/Tools/ $\mathrm{msa} / \mathrm{clustalo} /$ ) was used for alignment and comparison of motifs.

\section{Drosophila stocks and cytology}

The following mutant and transgenic flies were used: ssp3 ${ }^{\text {CR00740-TG4.0 }}$ (Bloomington-\#80635), Df(2 L)ED1203 (Bloomington \#8935) and ssp3 upstream activated sequence [UAS]-RNA interference (RNAi) (VDRC \#105858). Testisspecific expression of the RNAi construct was achieved using vasa-Gal4 (DGRC \#109997), bam-Gal 4 (Bloomington \#80579), nanos-Gal4 $4^{11}$ and traffic jam-Gal4 (DGRC \#104055). Oregon R or the Gal4-expressing lines were used as controls.

To analyse male meiosis, testes dissected from pupae or young adults were fixed as described in Bonaccorsi et al. ${ }^{12}$ Mutant pupae were easily recognised after rebalancing the $s s p 3$ mutations over the $C y O-T b A$ balancer. ${ }^{13}$ After two washes in phosphate-buffered saline (PBS), slides were air dried and incubated overnight at $4^{\circ} \mathrm{C}$ with the following primary antibodies diluted in PBS: monoclonal mouse anti-alpha tubulin (1:1000, Sigma-Aldrich) and rabbit anti-DSpd-2 (1:3500). ${ }^{14}$ Slides were washed twice in PBS for $10 \mathrm{~min}$ and then incubated for 1 hour at room temperature with FITC-conjugated goat anti-mouse (1:20, Jackson Laboratories) and Cy3-conjugated anti-rabbit IgGs (1:100, Jackson Laboratories). In all cases, slides were mounted in Vectashield H-1200 with 4',6-diamidine-2'-phenylindole dihydrochloride (DAPI) to stain DNA and examined using a Zeiss Axioplan fluorescence microscope equipped with a cooled charged-coupled device or camera (Photometrics CoolSnap HQ).

\section{Generation of knockout flies}

To generate ss 3 knockout flies, appropriate guide RNA sequences were identified using CHOPCHOP online (http://chopchop.cbu. uib.no/). ${ }^{15}$ The selected sgRNA sequences, 5'-GCCAGTGTAGGATGCGGCGG-3' and 5'-GGATTGTGAAGTTCAGCTGG-3', were cloned into a pU6-BbsI-chiRNA plasmid according to flyCRISPR U6-gRNA (chiRNA) cloning protocol (https:// flycrispr.org/protocols/grna/). ${ }^{16}$ Then, $1 \mathrm{~kb}$ sequence stretches upstream and downstream of $s s p 3$ were cloned into the donor pHD-DsRed-attP vector. Injection of vectors and fly screening were carried out by BestGene.

\section{Clinical phenotyping and surgical testicular sperm extraction (TESE)}

The clinical investigation included sperm analyses; physical and ultrasound examination of the genitalia; blood hormonal panel, including follicle-stimulating hormone (FSH), luteinising hormone $(\mathrm{LH})$, testosterone and inhibin; and genetic tests, including karyotype and Y-chromosome microdeletion assay. Following demonstration of azoospermia, surgical TESE was performed. ${ }^{17}$ The fluid content of the specimen was evaluated under a microscope in order to find sperm cells. In order to release spermatozoa (SPZ) from the seminiferous tubules, the tissue was mechanically dispersed by mincing between two sterile slides, and the presence of sperm was examined (inverted microscope $\times 400$ magnification). Thereafter, the tissue specimen was aspirated using syringes of 17 and 18 gauge (Becton Dickinson, India) and suspended. The fluids of the suspension and the fluid content of the dishes were further centrifuged at $755 \mathrm{~g}$ for $15 \mathrm{~min}$, and the pellet was further examined microscopically to identify sperm cells. In addition, a fragment of testicular parenchyma was processed for histology.

\section{Testicular tissue staining}

Staining was performed as previously described. ${ }^{18}{ }^{19}$ Antigen retrieval of the sections was performed in heated 36\% urea solution (Millipore) using 5\% donkey serum (Biological Industries) as a blocking buffer. After removal of the blocking buffer, the following primary antibodies were added: monoclonal mouse anti-human Boule (BOULE antibody [B-2]: sc-166660. 1:50; Santa Cruz Biotechnology, California, USA), polyclonal rabbit anti-human SCAPER (\#HPA046253, 1:100; Sigma, California, USA) and/or mouse monoclonal anti-human melanoma-associated antigen A (MAGE) (MAGE-A antibody [6C1]: sc-20034. 1:100; Santa Cruz Biotechnology). After overnight incubation at $4^{\circ} \mathrm{C}$, slides were washed, and specific secondary antibodies (Jackson ImmunoResearch Laboratories, West Grove, Pennsylvania, USA) were added, depending on the primary antibodies: donkey anti-rabbit $\mathrm{Cy} 3$-conjugated $\mathrm{IgG}$ (1:700 in blocking buffer) and donkey anti-mouse Alexa Fluor 488-conjugated IgG (1:100 in blocking buffer). After washing, slides were dried and mounted in UltraCruz ${ }^{\mathrm{R}}$ Aqueous mounting medium with DNA dye DAPI (Santa Cruz Biotechnology). The control preparations were incubated in blocking buffer and then stained with the secondary antibodies. Slides were examined using a fluorescence microscope (Nikon Eclipse 50 I; Tokyo, Japan).

\section{Freestyle 293-F cell culture and transient transfection}

Freestyle 293 F cells, Freestyle 293 expression medium and anticlumping agent were from Thermo Fisher Scientific (Waltham, Massachusetts, USA); Pluronic F-68 was from Alfa Aesar Chemicals (Haverhill, Massachusetts, USA); and polyethyleneimine (PEI) Max was from Polysciences (Warrington, Pennsylvania, USA). Freestyle 293 F cells were grown in Freestyle 293 expression media supplemented with anti-clumping agent and $0.1 \%$ Pluronic F68, on an orbital shaker with constant shaking at 100 rpm in a $\mathrm{CO}_{2}$ incubator $\left(37^{\circ} \mathrm{C}, 8 \% \mathrm{CO}_{2}\right)$. When the cells reached $1 \times 10^{6}$ cells $/ \mathrm{mL}$ density, culture $(100 \mathrm{~mL})$ was spun down at $1200 \mathrm{rpm}$ for $5 \mathrm{~min}$ and resuspended in fresh media without anti-clumping agent or pluronic, and transfected with $100 \mu \mathrm{g}$ of plasmid DNA using PEI Max (Sigma) at 1:1 ratio. Cells were diluted twofold the next day, and sodium butyrate and pluronic were added to $3 \mathrm{mM}$ and $0.1 \%$ final concentration, respectively. Cells were harvested 2 days after transfection and were used for protein purification.

\section{Protein constructs and protein purification}

Human SCAPER cDNA was subcloned from mEGFP-WTSCAPER. ${ }^{3}$ Drosophila ssp3 (NM_136073.3) cDNA-containing plasmid was purchased from VectorBuilder (VectorBuilder, Illinois, USA). Both were cloned into pIYneo (Addgene \#52117) vectors using Gibson assembly. The resulting constructs contain an N-terminal cassette consisting of a $6 \times \mathrm{His}$ tag and tandem Strep-tags connected by a GS-linker, followed by superfolded green fluorescent protein (sfGFP) and a precision protease cleavage site. Both ssp3 and SCAPER constructs were expressed in Freestyle $293 \mathrm{~F}$ cells. Cell pellets were lysed in protein buffer 


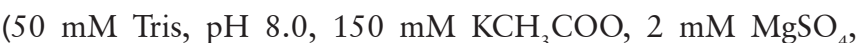
$1 \mathrm{mM}$ ethylene glycol-bis( $\beta$-aminoethyl ether)- $N, N, N^{\prime}, N^{\prime}-$ tetraacetic acid [EGTA], $10 \%$ glycerol) supplemented with $0.1 \%$ Triton-X100, 1 mM Dithiothreitol [DTT], $1 \mathrm{mM}$ phenylmethylsulfonyl fluoride [PMSF] and protease inhibitor mix (Promega). Proteins were affinity-purified using Strep XT beads (IBA). To identify purified proteins, western blot analysis was performed using anti Strep-tag II antibodies (NBP2-41076; Novus Biological Centennial, Colorado, USA).

\section{Total internal reflection fluorescence (TIRF) microscopy and MT-binding assay}

TIRF microscopy experiments were performed on a Nikon Ti2 stand, motorised ASI stage, quad-band filter cube, Nikon laser launch, EMCCD camera (iXon Ultra 897) using a highspeed filter wheel (Finger Lakes Instruments). TIRF chambers were assembled from acid-washed coverslips and double-sided sticky tape as previously described. ${ }^{20}$ Taxol-stabilised MTs were assembled with the incorporation of $\sim 10 \%$ DyLight-405 and biotin-labelled tubulin. Chambers were first incubated with 0.5 $\mathrm{mg} / \mathrm{mL}$ poly L-lysine [PLL]-poly ethylene glycol [PEG]-biotin (SuSoS, Switzerland) for $10 \mathrm{~min}$, followed by $0.5 \mathrm{mg} / \mathrm{mL}$ streptavidin for $5 \mathrm{~min}$. MTs were diluted into BRB80 Buffer $(80 \mathrm{mM}$ piperazine-N, $\mathrm{N}^{\prime}$-bis(2-ethanesulfonic acid) [PIPES], $\mathrm{pH}$ 6.8, 1 $\mathrm{mM} \mathrm{MgCl}, 1 \mathrm{mM}$ EGTA and $10 \mu \mathrm{M}$ taxol), then incubated in the chamber and allowed to adhere to the streptavidin-coated surface for $10 \mathrm{~min}$. Unbound MTs were washed away with TIRF buffer (90 mM (4-(2-hydroxyethyl)-1-piperazineethanesulfonic acid) [HEPES] $\mathrm{pH} 7.4,50 \mathrm{mM}$ potassium acetate, $2 \mathrm{mM} \mathrm{MgCl}$, $1 \mathrm{mM}$ EGTA, 10\% glycerol, 0.5\% Pluronic F-127, $0.1 \mathrm{mg} / \mathrm{mL}$ biotin-bovine serum albumin [BSA], $0.2 \mathrm{mg} / \mathrm{mL} \mathrm{\kappa}$-casein and 10 $\mu \mathrm{M}$ taxol). Unless otherwise stated, experiments were conducted in imaging buffer $(90 \mathrm{mM}$ HEPES, $\mathrm{pH} 7.4,50 \mathrm{mM}$ potassium acetate, $2 \mathrm{mM} \mathrm{MgCl}, 1 \mathrm{mM}$ EGTA, $10 \%$ glycerol, $0.5 \%$ Pluronic F-127, $0.1 \mathrm{mg} / \mathrm{mL}$ biotin-BSA, $0.2 \mathrm{mg} / \mathrm{mL}$ к-casein, 10 $\mu \mathrm{M}$ taxol, $2 \mathrm{mM}$ Trolox, $2 \mathrm{mM}$ protocatechuic acid, $\sim 50 \mathrm{nM}$ protocatechuate-3,4-dioxygenase and 2 mM ATP). Purified Ssp3 and SCAPER proteins were diluted 1:50 into imaging buffer and introduced into the chamber followed by immediate imaging. Purified 6His-Strep-sfGFP-BicD2N/BICD protein was used as a negative control. ${ }^{21}$ This experiment was repeated three times, and from each slide, 200 images of MTs and proteins were taken.

\section{RESULTS}

\section{Clinical phenotyping of hypergonadotropic azoospermia}

Two siblings, both previously reported to have BBS due to a homozygous SCAPER (NM 020843.2) c.2806delC; p.(L936*) truncation mutation, ${ }^{3}$ were referred for infertility studies: a 27-year-old patient (P1:V7) married to an apparently healthy woman, failing to conceive for 4 years, and his 31-year-old brother (P1:V6) (figure 1A).

In both individuals, three sperm analyses performed over a year have shown normal volume of ejaculate but no sperm cells, even after high-power microscopic examination of the sediment

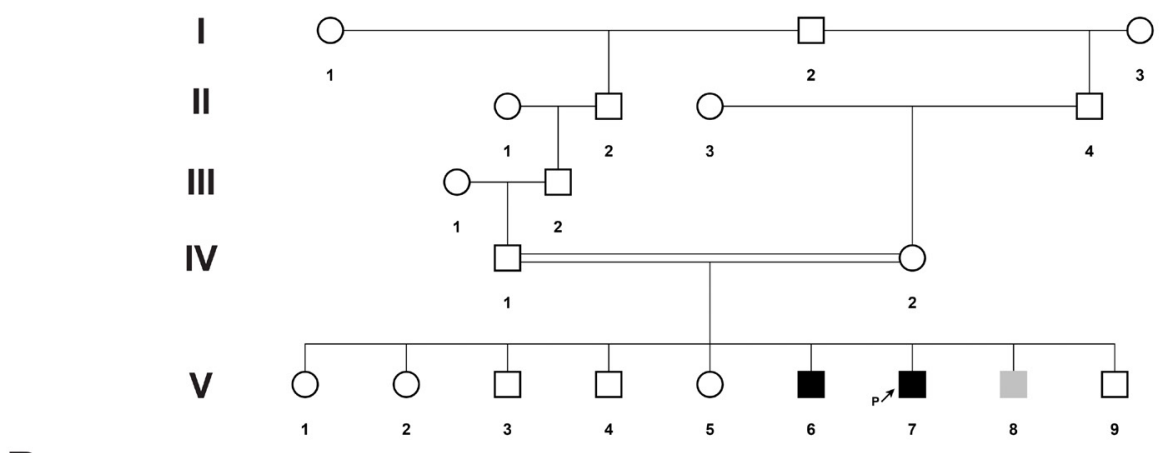

B
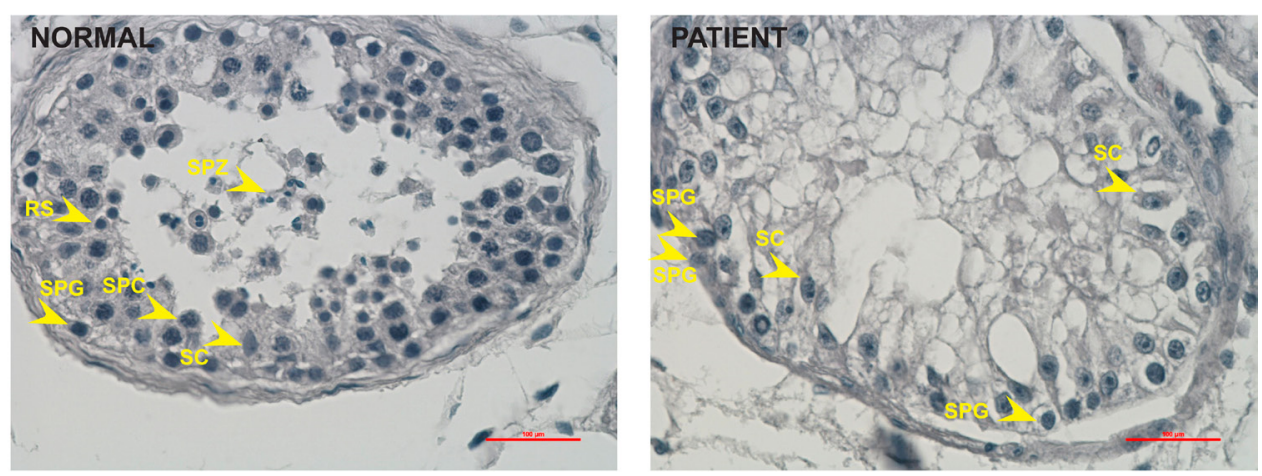

Figure 1 Pedigree and histological characterisation of testes from patients bearing biallelic SCAPER mutations. (A) pedigree of the consanguineous Bedouin kindred studied. Four patients (V5, V6, V7 and V8) were affected by Bardet-Biedl syndrome due to a homozygous SCAPER truncation mutation. Evaluation of the two mature male patients (both recently married; marked in black) revealed azoospermia. Note that V8 (marked in grey) could not be tested for azoospermia. (B) H\&E staining of a control testicular biopsy (left panel) showing a seminiferous tubule, including cells in all phases of spermatogenesis: SPG, SPC, RS, SPZ and SC. These cell types are identified according to their location in the seminiferous tubule and the shape of the nucleus. In the patient (right panel), the seminiferous tubules contain only SPG and SC, an evidence of maturation arrest. RS, round spermatid; SC, Sertoli cell; SCAPER, S-phase cyclin A-associated protein residing in the endoplasmic reticulum; SPC, spermatocyte; SPG, spermatogonia; SPZ, spermatozoa. 
A
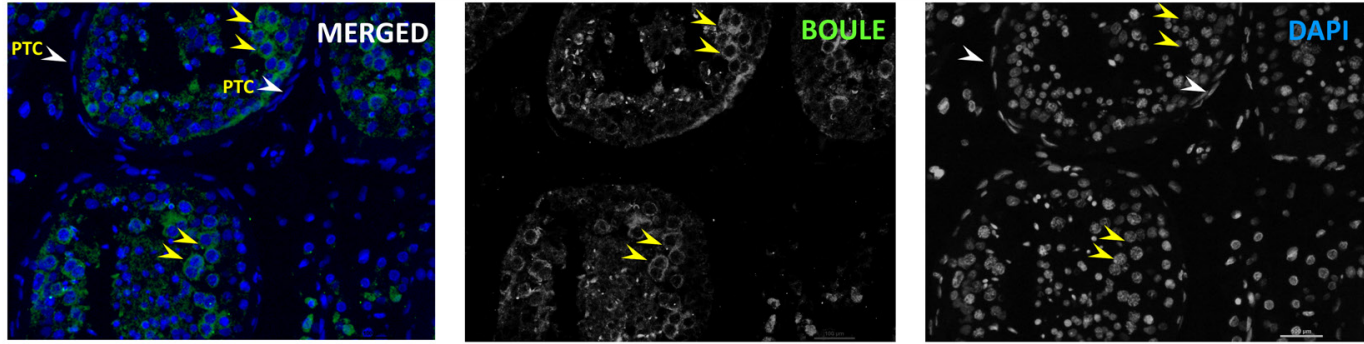

B
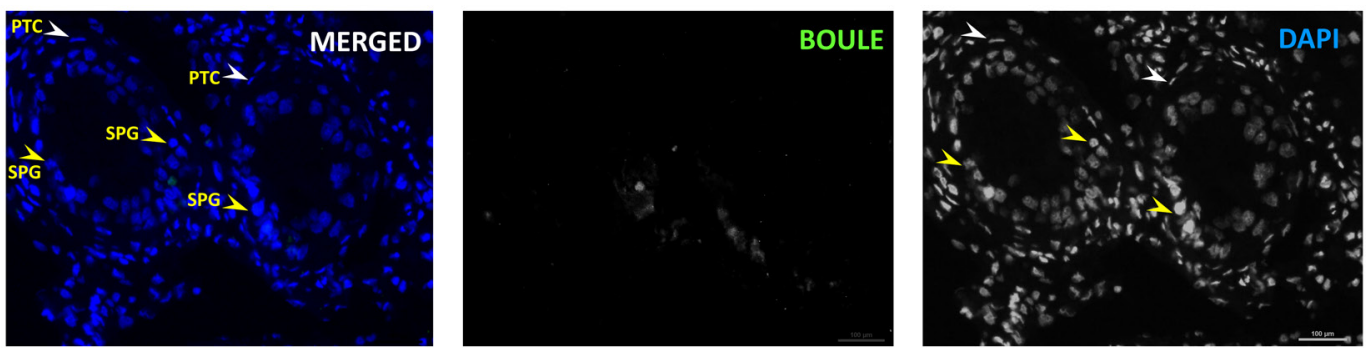

C
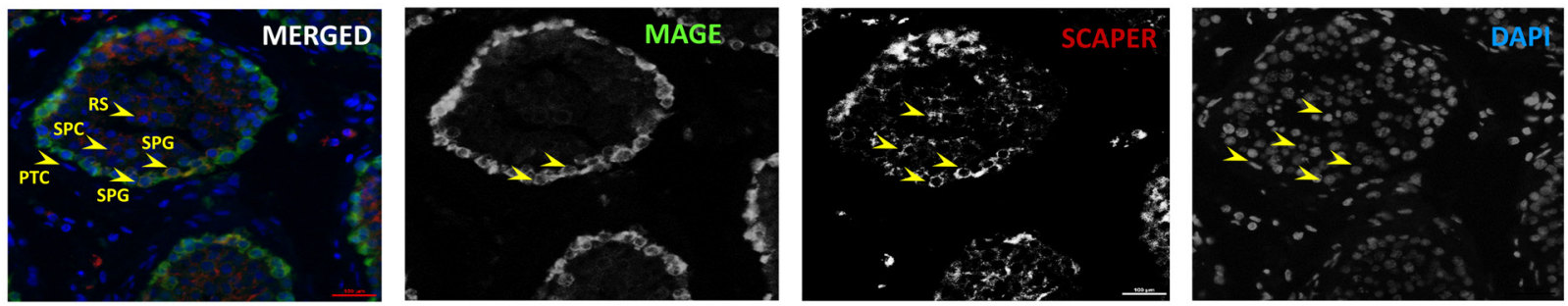

D
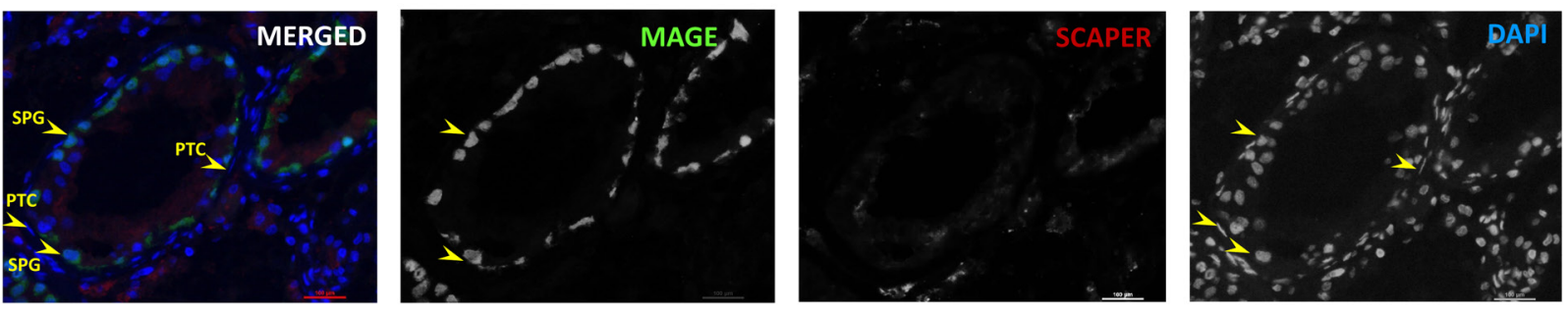

Figure 2 Cytological analysis of testicular tissue from patients bearing biallelic SCAPER mutations. (A,B) Biopsies from control (A) and affected patient (B) immunostained for Boule that specifically marks meiotic cells (green). The sections were also stained with DAPI (blue) to identify the germ cell nuclei within the seminiferous tubules. SPGs and PTCs are indicated by yellow and white arrowheads, respectively. (C,D) Double immunofluorescence for melanomaassociated antigen A (MAGE) (green, a specific marker for SPG) and SCAPER (red) in control (C) and patient's (D) biopsies. In normal tissues, SCAPER is localised to SPG, as revealed by colocalisation of SCAPER (red) with the MAGE marker (green) and is detected in SPCs and RSs in normal testicular biopsy. In the biopsy of the patient, SCAPER could not be detected. Scale bar, $100 \mu \mathrm{m}$. DAPI, 4',6-diamidine-2'-phenylindole dihydrochloride; PTC, peritubular cell; RS, round spermatid; SCAPER, S-phase cyclin A-associated protein residing in the endoplasmic reticulum; SPC, spermatocyte; SPG, spermatogonia.

postcentrifugation. Individual P1:V7 underwent standard clinical evaluation. Karyotype and Y chromosome microdeletion assay were normal. Testicular size was at the lower limit of the norm (10-12 mL) with firm consistency and no varicocele. Hormonal tests demonstrated elevated FSH (22 mIU $\backslash \mathrm{mL})$, elevated LH (17 $\mathrm{mIU} \backslash \mathrm{mL})$ and total testosterone at the lower limit of the norm (2.58 ng $\backslash \mathrm{mL})$.

Testicular biopsies of individual $\mathrm{P} 1: \mathrm{V} 7$ showed maturation arrest (figure 1B). H\&E staining of testicular tissue of individual P1:V7 demonstrated only spermatogonial cells (spermatogonia (SPG)) and Sertoli cells (SCs), in contrast with control testicular tissue in which cells of all stages of spermatogenesis were evident: SPG, SC, SPCs, round spermatids (RSs) and SPZ (figure 1B). For further detailed analysis of the testicular tissues, we used several antibodies as markers for the different stages of meiosis. Most notably, immunostaining with Boule, a meiotic germ cell marker, ${ }^{19}$ demonstrated that, in contrast with normal tissue (figure 2A), in the biopsy of the patient, meiotic cells were completely absent (figure 2B). To examine the cellular localisation of SCAPER in the control and patient biopsies, preparations were immunostained for both SCAPER and MAGE, which specifically marks spermatogonial cells. $^{22} 23$ In normal tissues, SCAPER was localised to SPG, as revealed by colocalisation of SCAPER (red) with the MAGE marker (green) (orange in the merged picture, figure 2C). In addition, SCAPER was detected in SPCs and RSs in normal testicular biopsy (figure 2C). As expected, in the biopsy of the patient, SCAPER could not be detected, while SPG staining by anti-MAGE antibodies was evident (figure 2D). No staining was present in control and patient biopsies incubated with secondary antibodies only (data not shown).

\section{Drosophila ssp3 null mutants are viable and female fertile but male sterile}

SCAPER is conserved throughout evolution (figure 3A). Two highly conserved motifs were found in all orthologues: SCAPER_N (PF16501) and structural maintenance of chromosomes (or chromosome segregation ATPases, NCBI-CDD 224117). 
A

H.sapiens |SCAPER| NP_065894.2|

\begin{tabular}{|c|c|c|c|}
\hline 1 (aa) & $91-182(5.3 e-44,100 \%)$ & $536-773(4 \mathrm{e}-12,100 \%)$ & 1400 \\
\hline
\end{tabular}

M.musculus |SCAPER| NP_001074810.1|

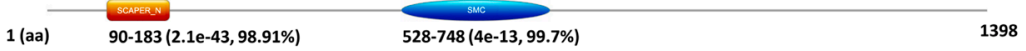

D.rerio |SCAPER| NP_001116519.1|

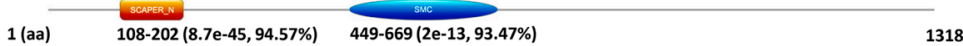

D.melanogaster |SSP3| NP_609917.2|

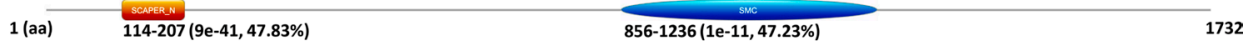

C.elegans |Y6B3B.4| NP_493409.3|

1 (aa) $18-109(1.5 \mathrm{e}-20,33.71 \%) \quad 359-669 \quad(2 \mathrm{e}-06,31.36 \%) \quad 1207$

B

pHD-DsRed-attP
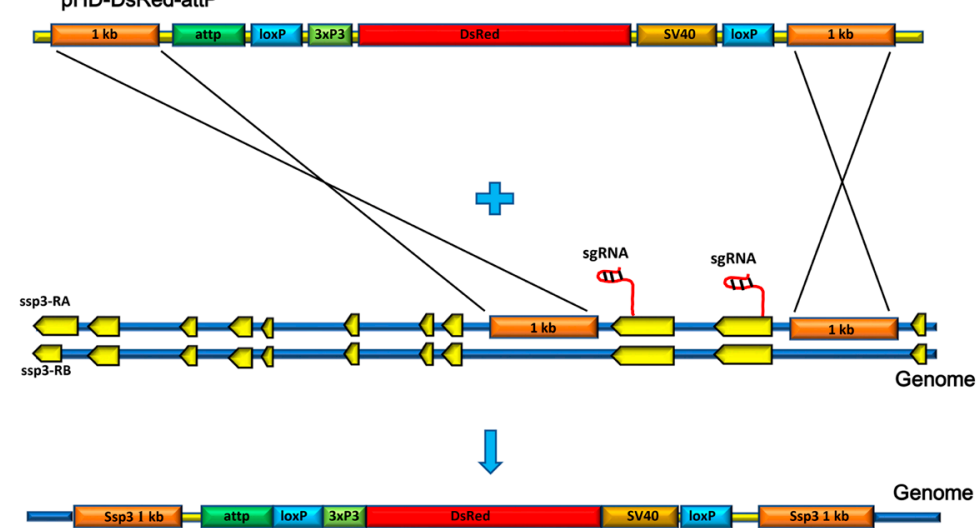

C

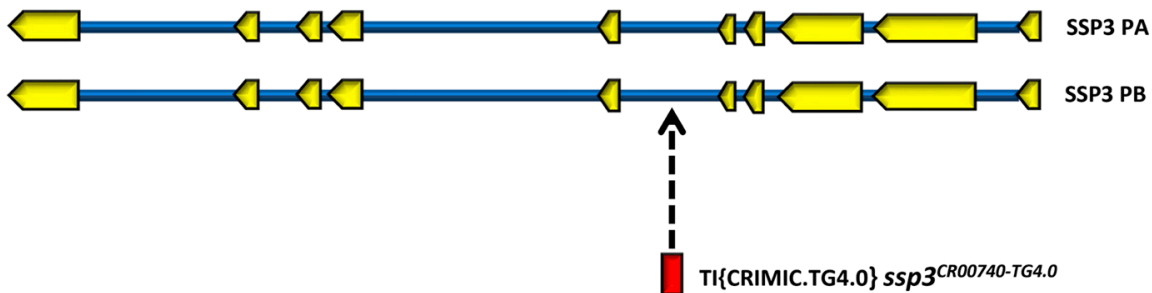

Figure 3 Analysis of the SCAPER orthologues and CRISPR-mediated generation of ssp3 null mutants. (A) Domain structure of SCAPER orthologues and conservation of recurring motifs across species. Two highly conserved motifs are found: 'SCAPER_N' (rectangle) and SMC (ellipse). Above each diagram: species| gene name|NCBI gene number. Below each diagram: numbers outside parenthesis mark the amino acid -aa- numberldomain spanning range; within parenthesis, MotifFinder calculated E-value for alignment against query database, per cent identity against Homo sapiens parallel domain, created by Clustal2.1). (B) Schematic diagram illustrating the molecular structure of the ssp3 locus and generation of ssp3 KO flies (null alleles) using CRISPR-mediated HDR. Exons contained in the two ssp3 isoforms are shown in yellow. Red arrows represent the binding sites of the forward and reverse primers used for genotyping. (C) Diagram of the ssp3 mutant allele containing a 'Trojan-GAL4' gene trap sequence inserted into an intron. The 'Trojan GAL4' element truncates the trapped gene product and expresses the GAL4 protein under the control of the ssp3 regulatory sequences. HDR, homology-directed repair; NCBI, National Center for Biotechnology Information; SCAPER, S-phase cyclin A-associated protein residing in the endoplasmic reticulum; SMC, structural maintenance of chromosome.

In order to test whether SCAPER is essential for spermatogenesis across species and to further delineate its role in this process, we examined the effect of loss of function mutations in the
Drosophila SCAPER orthologue ssp3. Using the CRISPR/Cas9 methodology, we generated five independent ssp3 knockout mutant alleles (figure 3B). Because all five alleles are virtually 
identical in their molecular structure, we designated them as M1 through M5, and we globally referred to them as $s s p 3^{K O}$. We also used an additional ssp3 mutant allele, ssp3 ${ }^{\text {CR00740-TG4.0 }}$ (called hereafter $s s p 3^{T G 4}$ ) (figure $3 \mathrm{C}$ ). Flies homozygous or hemizygous (over $D f(2 L) E D 1203$ that removes ssp3) for each of the six ssp3 mutations were fully viable and female fertile but were completely male sterile. We also tested several heteroallelic mutant combinations, including $s s p 3^{T G 4} / s s p 3^{K O}$, and found that they are viable and female fertile but male sterile. In all cases, fertility was assayed by crossing mutant males and females to wild-type virgin females and males, respectively. Although ssp3 is heavily expressed in many Drosophila tissues, including imaginal discs, ovaries and testes (FlyBase: modENCODE_mRNA-Seq_ tissues), our findings clearly show that it is required only for male fertility.

Next, we combined the UAS/Gal4 technology with RNAi to ascertain whether $s s p 3$ is required for spermatogenesis and to define the cells within the testis where ssp3 is required. We used a UAS-RNAi construct against ssp3 and the following Gal4 lines: vasa-Gal4, bag of marbles (bam)-Gal4, nanos (nos)-Gal4 and traffic jam $(t j)$-Gal4. Whereas the first three Gal4 lines are expressed in germline cells, $t j$-Gal4 is expressed in somatic gonadal cells. ${ }^{24}$ vasa-Gal4 is expressed in all germ cells from germline stem cells (GSCs) to SPCs ${ }^{25}$; bam-Gal4 is expressed in late stage SPG and SPCs ${ }^{26}$; and nos-Gal4 is expressed in GSC and SPG and very early SPCs. ${ }^{11}$ We found that RNAi-mediated downregulation of ssp3 with the vasa-Gal4 and bam-Gal4 drivers but not with the nos-Gal4 and $t j$-Gal4 driver lines leads to complete male sterility. These data suggest that ssp3 is required during spermatogonial and early SPC stages.

\section{Drosophila ssp3 is specifically required for gametogenesis in the male germline}

To define the defect leading to male sterility, we first examined the spermatids of homozygous $s s p 3^{M 1}$ and $s s p 3^{M 3}$ adult males. Meiosis in wild-type males produces 64 spermatids, each containing a nucleus and a mitochondrial derivative (or nebenkern). In living testes at the onion stage, spermatid nuclei and nebenkerne have similar sizes but are easily distinguished because they are phase-light and phase-dense, respectively (figure 4A).

Errors in chromosome segregation result in spermatid nuclei of different sizes. ${ }^{27}$ Cytokinesis failure abolishes mitochondria partitioning between the daughter cells, resulting in spermatids containing abnormally large nebenkerne associated with multiple nuclei. ${ }^{28}$ Examination of testes of both $s s p 3^{M 1}$ and $s s p 3^{M 3}$ flies revealed very few (if any) normal spermatids $(n=200$ spermatids per mutant). In both mutants, most nuclei and nebenkerne were of very different sizes and the nucleus-nebenkern association was often disrupted (figure 4B,C). This phenotype is diagnostic

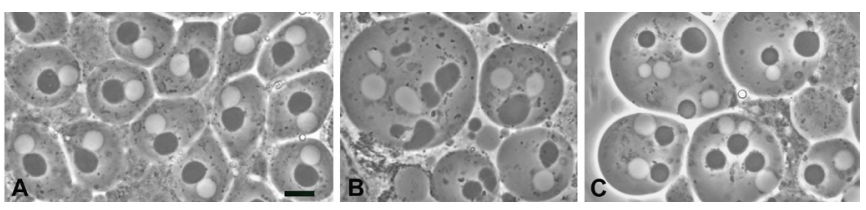

Figure 4 Mutations in ssp3 result in defective spermatids in Drosophila: $(A-C)$ Live onion stage spermatids from wild type $(A), \operatorname{ssp}^{M 1}(B)$ and ssp3 $3^{M 3}(C)$ mutants. Note that wild-type spermatids contain phase light nuclei and phase-dense nebenkerne of similar sizes. In contrast, in ssp3 mutants, nuclei and nebenkerne have very different sizes, a phenotype diagnostic of defects in both chromosome segregation and cytokinesis. Scale bar, $10 \mu \mathrm{m}$.
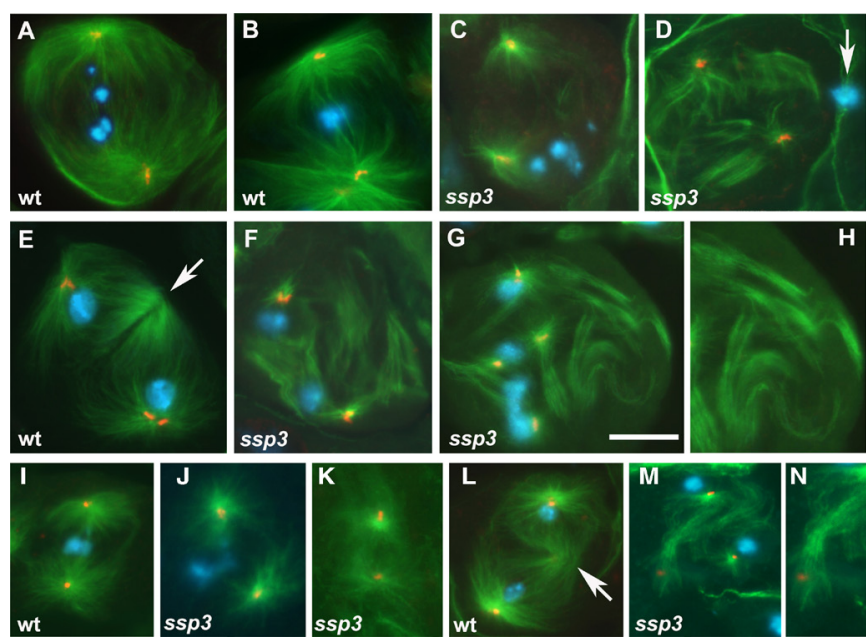

Figure 5 Mutations in ssp3 disrupt Drosophila male meiosis. (A-C) First male meiotic division in wt and ssp3 null mutants stained for $\alpha$-tubulin (green), Spd2 (red) and DNA (blue). (A) wt prometaphase I. (B) wt metaphase I. (C) Prometaphase I from an ssp $3^{M 1}$ mutant with the chromosomes misplaced with respect to the spindle axis. (D) Metaphase I from an $\mathrm{ssp}^{\mathrm{M3}}$ mutant with the chromosomes (arrow) located outside the spindle. (E) wt telophase I with a prominent central spindle (arrow). (F) Telophase I-like figure from an ssp3M1 mutant, devoid of a central spindle and showing irregular MT bundles. $(\mathrm{G}, \mathrm{H})$ Telophase I-like figure from an ssp3M3 mutant; the cell shown is probably hyperploid; note that it lacks a central spindle and instead exhibits irregular MT bundles, enlarged in $\mathrm{H}$. (I-N) Second meiotic division in wt and ssp3 null mutants. (I) wt metaphase II. (J) Metaphase II from an ssp3M1 mutant, with misplaced chromosomes laying outside the spindle. (K) Prometaphase/metaphase spindle devoid of chromosomes from an ssp3M3 mutant (see text for explanation on the origin of this peculiar type of meiosis II figures). (L) wt telophase II showing a typical central spindle (arrow). (M,N) Telophase II-like figure from an ssp3M1 mutant, showing irregular MT bundles, enlarged in N. Scale bar, 10 $\mu \mathrm{m}$. MT, microtubule; wt, wild type.

of failures in both chromosome segregation and cytokinesis (see for example $\mathrm{e}^{2930}$ ).

The finding that loss of ssp3 results in defective spermatids prompted us to examine meiotic divisions in fixed testes from $s s p 3^{M 1}$ and $s s p 3^{M 2}$ mutants; preparations were immunostained for tubulin and the centrosome marker Spd2, and counterstained for DNA (with DAPI). In both mutants, virtually all divisions were abnormal. In cells undergoing either the first or the second meiotic division, the MTs emanating from the centrosomes did not appear to interact properly with the chromosomes, so that the chromosomes were dispersed within the dividing SPC (figure 5C,J). Sometimes, the chromosomes were found outside the spindle (figure 5D), while in other cases, they were associated with a single pole (figure 5C). If the latter event were to occur during the first meiotic division, it would give rise to highly abnormal second meiotic divisions such as meiosis II spindles containing an unreduced chromosome complement (eight chromosomes) and spindles devoid of chromosomes (figure $5 \mathrm{~K}$ ), as previously observed in other Drosophila mutants. ${ }^{31-33}$ We did observe several meiosis II 'empty' spindles (11/62) and meiosis II spindles that appeared to contain more than four chromosomes (figure $5 \mathrm{~K}$ ). However, due to our fixation method that does not preserve chromosome morphology, we were unable to count chromosomes in the latter spindles.

We also found that meiotic cells of $s s p 3^{M 1}$ and $s s p 3^{M 3}$ mutants were unable to form regular central spindles. Wild-type primary 
and secondary SPCs form prominent hourglass-shaped spindles that are constricted in the middle by the cytokinetic ring (figure 5E, arrow). In contrast, in ssp3 mutant cells in which some chromosome segregation has occurred, we saw several irregular MT bundles dispersed within the cell without any specific orientation (figure $5 \mathrm{~F}, \mathrm{G}, \mathrm{H}, \mathrm{M}, \mathrm{N}$ ), Because the integrity of the central spindle is essential for contractile ring formation and cytokinesis, ${ }^{34} 35$ the cytokinesis defect observed in ssp3 mutants is easily explained by their inability to assemble a central spindle.

In a few 16 cell cysts of mature primary SPCs of ssp3 mutants, we observed nuclei that are substantially larger than the other nuclei in the cyst. In wild-type flies, these cysts invariably exhibit nuclei of nearly identical sizes. Thus, the large primary SPC nuclei observed in ssp3 mutants are the likely consequence of defects in the spermatogonial divisions. Consistent with this interpretation, we observed meiotic divisions of cells that appear to be tetraploid; one of these cells is shown in figure $5 \mathrm{G}$. These findings imply that $s s p 3$, in addition to an essential role in male meiosis, plays a function in gonial cell division.

\section{SCAPER and Ssp3 directly bind MTs in vitro}

Our data suggest that ssp3 is required for proper MT behaviour during male meiosis. Consistent with this finding, it has been previously shown that the $\mathrm{Ssp} 3$ protein localises to metaphase spindles of Drosophila S2 cells. ${ }^{10}$ Moreover, our previous work has suggested that the SCAPER protein localises to both MTs and primary cilia in human cells. ${ }^{3}$ Thus, we asked whether the Ssp3 and SCAPER proteins have intrinsic abilities to bind MTs in vitro, using a fluorescence-based MT-binding assay (see the Methods section). We isolated 6His-Strep-sfGFP-tagged Ssp3, SCAPER and BicD2N (negative control) proteins from mammalian HEK293 cells (figure 6). In extracts, we could detect fulllength tagged SCAPER and Ssp3 proteins and some degradation products (figure 6A) using an antibody against the N-terminal Strep purification tag. Using TIRF microscopy, we found that both tagged proteins robustly colocalise with immobilised MTs (figure 6B), indicating that both Ssp3 and SCAPER directly bind MTs. In contrast, BicD2N did not show any associations with the MTs (figure 6C).

\section{DISCUSSION}

Azoospermia, identified in $\sim 1 \%$ of all men and $10 \%-20 \%$ of infertile men, is defined as the complete absence of SPZ in the centrifuged ejaculate in high-powered microscope examination on at least two occasions. While $\sim 40 \%$ of azoospermia cases are due to genital tract obstruction at various levels, most cases are due to spermatogenesis failure or extremely low sperm production, with spermatogenesis ensuing in only few seminiferous tubules to different intermediate degrees of germ cell development. ${ }^{36}$ The various degrees of spermatogenesis disruption are reflected by the histopathology of the testicular parenchyma: absence of sperm cells due to an SC-only histology pattern; maturation arrest, where spermatogenesis is arrested at one or more levels; and hypospermatogenesis, where complete spermatogenesis is present, but only few mature sperm cells can be observed, or mixed patterns. ${ }^{37}$

One of the known causes of non-obstructive male infertility is BBS. It is long known that hypogonadism is one of the main characteristics of BBS, and affected males are usually infertile due to primary gonadal failure. ${ }^{38}$ As most BBS disease-causing genes are involved in cilia biogenesis and function, the subfertility is believed to be a result of defective sperm tails. ${ }^{39}$ Specifically, Bbs7 knockout mice were characterised by abnormal sperm flagellar axonemes, while absence of sperm flagella was demonstrated in Bbs1 $1^{M 390 R / M 390 R}$ knockin, Bbs 2 knockout, $B b s 4$ knockout and $B b s 6$ knockout mice. ${ }^{40-44}$ We have recently shown that a biallelic mutation in SCAPER causes BBS and affects primary cilia. ${ }^{3}$ We now demonstrate hypergonadotropic azoospermia in male patients carrying SCAPER mutation. While in testis biopsies of these patients spermatogonial and SCs were normally present, incomplete germ cell maturation was evident, with the complete absence of meiotic cells. Furthermore, the SCAPER protein localised to the spermatogonial cells in normal
A

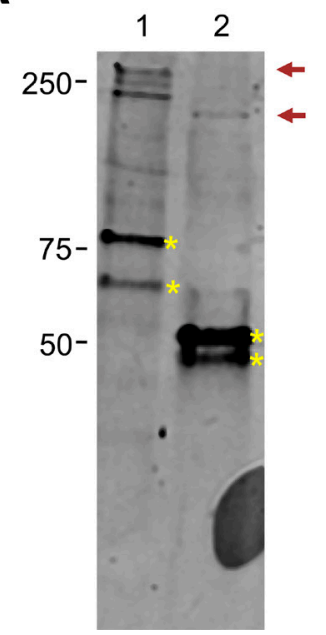

B

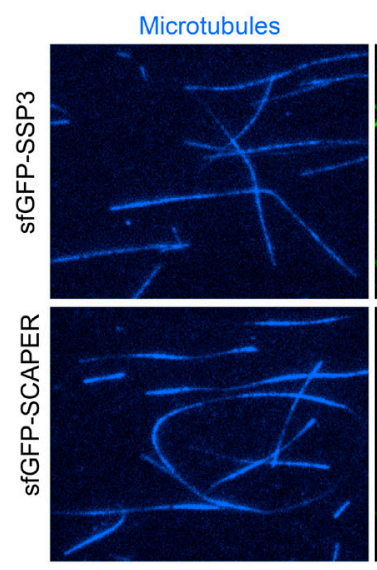

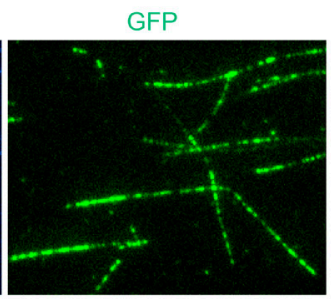

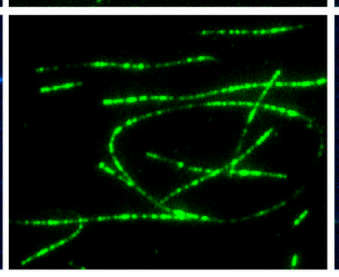

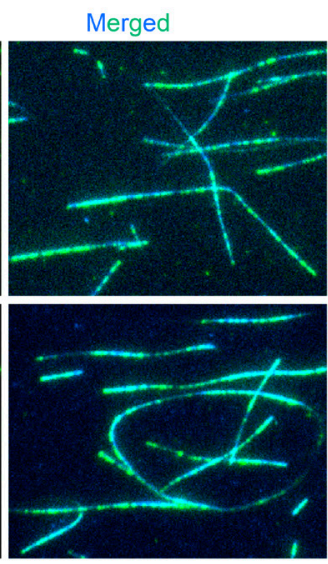

Microtubules/GFP-BicD2N

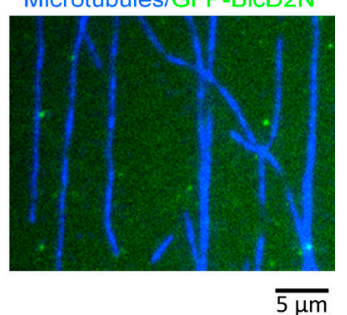

Figure 6 Purified SCAPER and Ssp3 directly bind MTs. (A) Western blot of affinity purified 6His-Strep-sfGFP-Ssp3 (lane 1) or 6His-Strep-sfGFP-SCAPER (lane 2) using an antibody against the N-terminal Strep-tag. Pink arrows indicate the expected MW of the fusion proteins (220 kDa for 6His-Strep-sfGFPSsp3 and 186 kDa for 6 His-Strep-sfGFP-SCAPER); yellow asterisks indicate prominent degradation products containing the N-terminal Strep-tag. (B) TIRF-M images of immobilised bovine brain MTs (blue) and 6His-Strep-sfGFP-tagged proteins (green), highlighting the robust direct association of these proteins with MTs. (C) 6his-Strep-sfGFP-tagged BicD2N (green, $20 \mathrm{nM}$ ) does not bind to MTs (blue) demonstrating the binding specificity of Ssp3 and SCAPER in this assay. Scale bar, 5 Hm. MT, microtubule; 6His, polyhistidine tag; Strep, Strep tag; sfGFP, superfolded green fluorescent protein; TIRF, total internal reflection fluorescence. 
control specimens, yet was not found in testes of affected individuals, consistent with the instability of the mutant SCAPER protein. ${ }^{3}$ As SPZ fail to develop in SCAPER null mutant patient due to meiotic failure in the earlier phase, we cannot rule out an additional role for SCAPER in sperm flagella formation or structure, as one would have expected based on the findings in the various mice $B b s$ mutants. ${ }^{40-44}$

The azoospermia of patients carrying a presumably null SCAPER mutation is consistent with the male infertility seen in SCAPER null mutant mice (Scaper ${ }^{\mathrm{tm} 1 \mathrm{~b}(\mathrm{EUCOMM}) \mathrm{Hmgu}}$ ) described by the International Mouse Phenotyping Consortium, ${ }^{45}$ as well as the presence of SCAPER RNA in mouse testes (GUDMAP Consortium, GUDMAP: the GenitoUrinary Development Molecular Anatomy Project;www.gudmap.org). ${ }^{46}$

Drosophila male meiosis is a well-characterised model system that is particularly advantageous due to the large size of both centrioles and spindles. In addition, examination of spermatid morphology in vivo permits easy and reliable assessment of meiotic abnormalities. Our Drosophila studies showed that the crucial role of SCAPER in spermatogenesis and allowed a detailed analysis of the phenotype caused by null mutations in the fly orthologue of SCAPER. We found that male meiotic cells of ssp3 mutants are defective in MT-chromosome interaction and do not exhibit regular central spindles. Instead, they display a phenotype that, to the best of our knowledge, has never been observed in any Drosophila male meiotic mutant, namely, anatelophase figures showing several randomly oriented bundles of parallel MTs and no central spindle. Our finding that meiotic spindle MTs of $s s p 3$ mutant males do not correctly interact with the kinetochores is subject to two interpretations. This phenotype could be the outcome of a defect in meiotic kinetochore structure/function or the consequence of a more general defect in MT dynamic behaviour that would prevent proper MT-kinetochore interaction. Based on the meiotic anaphase/telophase phenotypes observed in mutant ssp 3 males (figure 5), we strongly favour the second alternative.

It has been previously shown that asterless mutants that are devoid of asters and exhibit highly irregular meiotic metaphases and anaphases can assemble regular central spindles. ${ }^{47}$ Morphologically normal hourglass-shaped meiosis II central spindles have been also observed in secondary SPCs that assemble a spindle in the complete absence of chromosomes, following a complete failure of chromosome segregation in the first division, for example, in Topoisomerase II mutants ${ }^{31} 33$ and in mitch mutants that are defective in kinetochore assembly. ${ }^{32}$ In contrast, irregular central spindles have been described in several mutants with altered MT-related functions. The genes specified by these mutants include the kinesin-like proteins Klp3A and pavarotti that are enriched in the MTs of the central spindle midzone ${ }^{4849}$ and fascetto that specifies a protein homologous to the Ase $1 \mathrm{p} /$ PRC1 family that binds the central spindle MTs. ${ }^{50}$ Collectively, these results suggest that central spindle formation is independent of both the presence of chromosomes and the mode of MT nucleation, and relies on proteins that control MT dynamics or stability.

The hypothesis that the meiotic phenotype observed in Drosophila males is the consequence of an abnormal MT behaviour is strongly supported by our finding that both Ssp3 and SCAPER bind MTs in vitro. This hypothesis is also consistent with the observation that, in S2 cells, Ssp3-GFP is enriched at the spindles and its RNAi-mediated depletion leads to the formation of short spindles. ${ }^{10}$ However, a role of Ssp3 in mitotic spindle assembly seems to be specific for S2 cells, as $s s p 3$ mutant flies develop normally. We examined larval brain preparations of the mutants stained for tubulin, Spd2 and DNA and found no obvious departures from normality in the mitotic divisions of brain cells (data not shown).

In conclusion, to the best of our knowledge, SCAPER is the first example of a human gene responsible for BBS that is required for male meiosis and the ensuing sperm formation. We have also shown that the Drosophila orthologue of SCAPER, ssp3, is specifically required for meiotic spindle formation in males. The finding that both SCAPER and Ssp3 bind MTs in vitro raises the intriguing possibility that both proteins control MT dynamics during male meiosis, highlighting a common feature between human and Drosophila male meiosis.

\section{Author affiliations}

${ }^{1}$ The Morris Kahn Laboratory of Human Genetics, National Institute for Biotechnology in the Negev and Faculty of Health Sciences, Ben-Gurion University of the Negev,

Beer-Sheva, Israel

${ }^{2}$ Department of Life Sciences, Ben-Gurion University of the Negev, Beer-Sheva, Israel ${ }^{3}$ Dipartimento di Biologia e Biotecnologie "C. Darwin", Sapienza University of Rome, Rome, Italy

${ }^{4}$ Istituto di Biologia e Patologia Molecolari Consiglio Nazionale delle Ricerche, Roma, Italy

${ }^{5}$ Shraga Segal Department of Microbiology, Immunology and Genetics, Ben-Gurion University of the Negev Faculty of Health Sciences, Beer-Sheva, Israel

${ }^{6}$ The Center of Advanced Research and Education in Reproduction (CARER), BenGurion University of the Negev Faculty of Health Sciences, Beer-Sheva, Israel

${ }^{7}$ Department of Molecular and Cellular Biology, UC Davis, Davis, California, USA

${ }^{8}$ Southern District, Clalit Health Services, Beer-Sheva, Israel

${ }^{9}$ Fertility and IVF Unit, Department of Obstetrics and Gynecology, Soroka University Medical Center, Beer-Sheva, Israel

${ }^{10}$ Genetics Institute, Soroka University Medical Center, Beer-Sheva, Israel

Contributors UA initiated the study. UA, OSB, YL, MH and OW contributed to its conception and design, and together with $\mathrm{EL}, \mathrm{SB}, \mathrm{MG}$ and $\mathrm{LG}$ drafted the manuscript. $O W, Y L, A B, S B, L G, M G, M H, A A M, R J M, K O, S E R, I H-V, E L, O S B$ and UA acquired and analysed data. EL, IH-V, SEL and OSB provided the clinical data.

Funding These studies were funded in part by the Morris Kahn Foundation and supported through the National Knowledge Center for Rare/Orphan Diseases sponsored by the Israeli Ministry of Science, Technology and Space (to OSB), and by Associazione Italiana per la Ricerca sul Cancro (IG grant 20528 to MG). RJM is supported by grant R35GM124889 from the NIH.

Competing interests None declared.

Patient consent for publication Not required.

Ethics approval This study was done following Soroka Medical Center institutional review board approval (\#5071G and \#4538) with informed consent of studied individuals or their legal guardians.

Provenance and peer review Not commissioned; externally peer reviewed. Data availability statement Data are available upon reasonable request.

ORCID iD

Uri Abdu http://orcid.org/0000-0003-1226-0750

\section{REFERENCES}

1 Tatour Y, Sanchez-Navarro I, Chervinsky E, Hakonarson H, Gawi H, Tahsin-Swafiri S, Leibu R, Lopez-Molina MI, Fernandez-Sanz G, Ayuso C, Ben-Yosef T. Mutations in SCAPER cause autosomal recessive retinitis pigmentosa with intellectual disability. $J$ Med Genet 2017;54:698-704.

2 Kahrizi K, Huber M, Galetzka D, Dewi S, Schröder J, Weis E, Kariminejad A, Fattahi Z, Ropers H-H, Schweiger S, Najmabadi H, Winter J. Homozygous variants in the gene SCAPER cause syndromic intellectual disability. Am J Med Genet A 2019;179:12141225.

3 Wormser O, Gradstein L, Yogev Y, Perez Y, Kadir R, Goliand I, Sadka Y, El Riati S, Flusser H, Nachmias D, Birk R, Iraqi M, Kadar E, Gat R, Drabkin M, Halperin D, Horev A, Sivan S, Abdu U, Elia N, Birk OS. SCAPER localizes to primary cilia and its mutation affects cilia length, causing Bardet-Biedl syndrome. Eur J Hum Genet 2019;27:928-40.

4 Fasham J, Arno G, Lin S, Xu M, Carss KJ, Hull S, Lane A, Robson AG, Wenger O, Self JE, Harlalka GV, Salter CG, Schema L, Moss TJ, Cheetham ME, Moore AT, Raymond FL, Chen R, Baple EL, Webster AR, Crosby AH, NIHR Bioresource Rare Diseases Consortium. Delineating the expanding phenotype associated with SCAPER gene mutation. Am J Med Genet A 2019;179:1665-71. 
5 Jauregui R, Thomas AL, Liechty B, Velez G, Mahajan VB, Clark L, Tsang SH. SCAPERassociated nonsyndromic autosomal recessive retinitis pigmentosa. Am J Med Genet A 2019;179:312-6.

6 Najmabadi H, Hu H, Garshasbi M, Zemojtel T, Abedini SS, Chen W, Hosseini M, Behjati F, Haas S, Jamali P, Zecha A, Mohseni M, Püttmann L, Vahid LN, Jensen C, Moheb LA, Bienek M, Larti F, Mueller I, Weissmann R, Darvish H, Wrogemann K, Hadavi V, Lipkowitz B, Esmaeeli-Nieh S, Wieczorek D, Kariminejad R, Firouzabadi SG, Cohen M, Fattahi Z, Rost I, Mojahedi F, Hertzberg C, Dehghan A, Rajab A, Banavandi MJS, Hoffer J, Falah M, Musante L, Kalscheuer V, Ullmann R, Kuss AW, Tzschach A, Kahrizi K, Ropers $\mathrm{HH}$. Deep sequencing reveals 50 novel genes for recessive cognitive disorders. Nature 2011;478:57-63.

7 Hu H, Kahrizi K, Musante L, Fattahi Z, Herwig R, Hosseini M, Oppitz C, Abedini SS, Suckow V, Larti F, Beheshtian M, Lipkowitz B, Akhtarkhavari T, Mehvari S, Otto S, Mohseni M, Arzhangi S, Jamali P, Mojahedi F, Taghdiri M, Papari E, Soltani Banavandi MJ, Akbari S, Tonekaboni SH, Dehghani H, Ebrahimpour MR, Bader I, Davarnia B, Cohen M, Khodaei H, Albrecht B, Azimi S, Zirn B, Bastami M, Wieczorek D, Bahrami G, Keleman K, Vahid LN, Tzschach A, Gärtner J, Gillessen-Kaesbach G, Varaghchi JR, Timmermann B, Pourfatemi F, Jankhah A, Chen W, Nikuei P, Kalscheuer VM, Oladnabi M, Wienker TF, Ropers H-H, Najmabadi H. Genetics of intellectual disability in consanguineous families. Mol Psychiatry 2019;24:1027-39.

8 Carss KJ, Arno G, Erwood M, Stephens J, Sanchis-Juan A, Hull S, Megy K, Grozeva D, Dewhurst E, Malka S, Plagnol V, Penkett C, Stirrups K, Rizzo R, Wright G, Josifova D, Bitner-Glindzicz M, Scott RH, Clement E, Allen L, Armstrong R, Brady AF, Carmichael J, Chitre M, Henderson RHH, Hurst J, MacLaren RE, Murphy E, Paterson J, Rosser E, Thompson DA, Wakeling E, Ouwehand WH, Michaelides M, Moore AT, Webster AR, Raymond FL, Aitman T, Alachkar H, Ali S, Allen L, Allsup D, Ambegaonkar G, Anderson J, Antrobus R, Armstrong R, Arno G, Arumugakani G, Ashford S, Astle W, Attwood A, Austin S, Bacchelli C, Bakchoul T, Bariana TK, Baxendale H, Bennett D, Bethune C, Bibi S, Bitner-Glindzicz M, Bleda M, Boggard H, Bolton-Maggs P, Booth C, Bradley JR, Brady AFA, Brown M, Browning M, Bryson C, Burns S, Calleja P, Canham N, Carmichael J, Carss KJ, Caulfield M, Chalmers E, Chandra A, Chinnery P, Chitre M, Church C, Clement E, Clements-Brod N, Clowes V, Coghlan G, Collins P, Cooper N, Creaser-Myers A, DaCosta R, Daugherty L, Davies S, Davis J, De Vries M, Deegan P, Deevi SVV, Deshpande C, Devlin L, Dewhurst E, Doffinger R, Dormand N, Drewe E, Edgar D, Egner W, Erber WN, Erwood M, Everington T, Favier R, Firth $H$, Fletcher D, Flinter F, Fox JC, Frary A, Freson K, Furie B, Furnell A, Gale D, Gardham A, Gattens M, Ghali N, Ghataorhe PK, Ghurye R, Gibbs S, Gilmour K, Gissen P, Goddard S, Gomez K, Gordins P, Gräf S, Greene D, Greenhalgh A, Greinacher A, Grigoriadou S, Grozeva D, Hackett S, Hadinnapola C, Hague R, Haimel M, Halmagyi C, Hammerton T, Hart D, Hayman G, Heemskerk JWM, Henderson RHH, Hensiek A, Henskens Y, Herwadkar A, Holden S, Holder M, Hu F, Huissoon A, Humbert M, Hurst J, James R, Jolles S, Josifova D, Kazmi R, Keeling D, Kelleher P, Kelly AM, Kennedy F, Kiely D, Kingston N, Koziell A, Krishnakumar D, Kuijpers TW, Kumararatne D, Kurian M, Laffan MA, Lambert MP, Lawrie A, Lear S, Lees M, Lentaigne C, Liesner R, Longhurst $H$, Lorenzo L, Machado R, Mackenzie R, MacLaren RE, Maher E, Maimaris J, Mangles S, Manson A, Mapeta R, Markus HS, Martin J, Masati L, Mathias M, Matser V, Maw A, McDermott E, McJannet C, Meacham S, Meehan S, Megy K, Mehta S, Michaelides M, Millar CM, Moledina S, Moore AT, Morrell N, Mumford A, Murng S, Murphy E, Nejentsev S, Noorani S, Nurden P, Oksenhendler E, Ouwehand WH, Papadia S, Park S-MM, Parker A, Pasi J, Patch C, Paterson J, Payne J, Peacock A, Peerlinck K, Penkett CJ, Pepke-Zaba J, Perry DJ, Pollock V, Polwarth G, Ponsford M, Qasim W, Quinti I, Rankin S, Rankin J, Rehnstrom K, Reid E, Rhodes CJ, Richards M, Richardson S, Richter A, Roberts I, Rondina M, Rosser E, Roughley C, Rue-Albrecht K, Samarghitean C, Sanchis-Juan A, Sandford R, Santra S, Sargur R, Savic S, Schulman S, Schulze H, Scott RH, Scully M, Seneviratne S, Sewell C, Shamardina O, Shipley D, Simeoni I, Sivapalaratnam S, Smith K, Sohal A, Southgate L, Staines S, Staples E, Stauss H, Stein P, Stephens J, Stirrups K, Stock S, Suntharalingam J, Tait RC, Talks K, Tan Y, Thachil J, Thaventhiran J, Thomas E, Thomas M, Thompson DA Thrasher A, Tischkowitz M, Titterton C, C-HH T, Toshner M, Treacy C, Trembath R, Tuna S, Turek W, Turro E, Van Geet C, Veltman M, Vogt J, von Ziegenweldt J, Noordegraaf AV, Wakeling E, Wanjiku I, Warner TQ, Wassmer E, Watkins H, Welch S, Westbury S, Wharton J, Whitehorn D, Wilkins M, Willcocks L, Williamson C, Woods G, Wort J, Yeatman N, Yong P, Young T, Yu P, Webster AR, Raymond FL, Allen L, Holden S, Holder $\mathrm{S}$, Allen $\mathrm{HL}$, Liesner R, Linger R, Longhurst $H$, Lorenzo L, Machado R, Mackenzie R, MacLaren RE, Maher E, Maimaris J, Mangles S, Manson A, Mapeta R, Markus HS, Martin J, Masati L, Mathias M, Matser V, Maw A, McDermott E, McJannet C, Meacham S, Meehan S, Megy K, Mehta S, Michaelides M, Millar CM, Moledina S, Moore AT, Morrell N, Mumford A, Murng S, Murphy E, Nejentsev S, Noorani S, Nurden P, Oksenhendler E, Ouwehand WH, Papadia S, Park S-MM, Parker A, Pasi J, Patch C, Paterson J, Payne J, Peacock A, Peerlinck K, Penkett CJ, Pepke-Zaba J, Perry DJ, Pollock V, Polwarth G, Ponsford M, Qasim W, Quinti I, Rankin S, Rankin J, Raymond FL, Rehnstrom K, Reid E, Rhodes CJ, Richards M, Richardson S, Richter A, Roberts I, Rondina M, Rosser E, Roughley C, Rue-Albrecht K, Samarghitean C, Sanchis-Juan A, Sandford R, Santra S, Sargur R, Savic S, Schulman S, Schulze H, Scott RH, Scully M, Seneviratne S, Sewell C, Shamardina O, Shipley D, Simeoni I, Sivapalaratnam S, Smith K, Sohal A, Southgate L, Staines S, Staples E, Stauss H, Stein P, Stephens J, Stirrups K, Stock S, Suntharalingam J, Tait RC, Talks K, Tan Y, Thachil J, Thaventhiran J, Thomas E, Thomas M, Thompson DA, Thrasher A, Tischkowitz M, Titterton C, C-HH T, Toshner M, Treacy C, Trembath R, Tuna S, Turek W, Turro E, Van Geet C, Veltman M, Vogt J, von
Ziegenweldt J, Vonk Noordegraaf A, Wakeling E, Wanjiku I, Warner TQ, Wassmer E, Watkins H, Webster AR, Welch S, Westbury S, Wharton J, Whitehorn D, Wilkins M, Willcocks L, Williamson C, Woods G, Wort J, Yeatman N, Yong P, Young T, Yu P, Noordegraaf AV, Wakeling E, Wanjiku I, Warner TQ, Wassmer E, Watkins H, Webster AR, Welch S, Westbury S, Wharton J, Whitehorn D, Wilkins M, Willcocks L, Williamson C, Woods G, Wort J, Yeatman N, Yong P, Young T, Yu P, Webster AR, Raymond FL, NIHR-BioResource Rare Diseases Consortium. Comprehensive rare variant analysis via whole-genome sequencing to determine the molecular pathology of inherited retinal disease. Am J Hum Genet 2017;100:75-90.

9 Tsang WY, Wang L, Chen Z, Sánchez I, Dynlacht BD. SCAPER, a novel cyclin Ainteracting protein that regulates cell cycle progression. J Cell Biol 2007;178:621-33.

10 Goshima G, Wollman R, Goodwin SS, Zhang N, Scholey JM, Vale RD, Stuurman $\mathrm{N}$. Genes required for mitotic spindle assembly in Drosophila $\mathrm{S2}$ cells. Science 2007;316:417-21.

11 Van Doren M, Williamson AL, Lehmann R. Regulation of zygotic gene expression in Drosophila primordial germ cells. Curr Biol 1998;8:243-6.

12 Bonaccorsi S, Giansanti MG, Cenci G, Gatti M. Methanol-acetone fixation of Drosophila testes. Cold Spring Harb Protoc 2011;2011:pdb.prot065763.

13 Lattao R, Bonaccorsi S, Guan X, Wasserman SA, Gatti M. Tubby-tagged balancers for the Drosophila X and second chromosomes. Fly 2011;5:369-70.

14 Giansanti MG, Bucciarelli E, Bonaccorsi S, Gatti M. Drosophila SPD-2 is an essential centriole component required for PCM recruitment and astral-microtubule nucleation. Curr Biol 2008; 18:303-9.

15 Labun K, Montague TG, Gagnon JA, Thyme SB, Valen E. CHOPCHOP V2: a web tool for the next generation of CRISPR genome engineering. Nucleic Acids Res 2016:44:W272-6.

16 Bier $\mathrm{E}$, Harrison MM, O'Connor-Giles KM, Wildonger J. Advances in engineering the fly genome with the CRISPR-Cas system. Genetics 2018;208:1-18.

17 Jungwirth A, Giwercman A, Tournaye H, Diemer T, Kopa Z, Dohle G, Krausz C, European Association of Urology Working Group on Male Infertility. European association of urology guidelines on male infertility: the 2012 update. Eur Urol 2012;62:324-32

18 Huleihel M, Nourashrafeddin S, Plant TM. Application of three-dimensional culture systems to study mammalian spermatogenesis, with an emphasis on the rhesus monkey (Macaca mulatta). Asian J Androl 2015;17:972.

19 Abofoul-Azab M, AbuMadighem A, Lunenfeld E, Kapelushnik J, Shi Q, Pinkas H, Huleihel M. Development of postmeiotic cells in vitro from spermatogonial cells of prepubertal cancer patients. Stem Cells Dev 2018;27:1007-20.

20 Tan R, Foster PJ, Needleman DJ, McKenney RJ. Cooperative accumulation of dyneindynactin at microtubule minus-ends drives microtubule network reorganization. Dev Cell 2018;44:233-47.

21 McKenney RJ, Huynh W, Tanenbaum ME, Bhabha G, Vale RD. Activation of cytoplasmic dynein motility by dynactin-cargo adapter complexes. Science 2014;345:337-41.

22 Arafat M, Har-Vardi I, Harlev A, Levitas E, Zeadna A, Abofoul-Azab M, Dyomin V, Sheffield VC, Lunenfeld E, Huleihel M, Parvari R. Mutation in TDRD9 causes nonobstructive azoospermia in infertile men.J Med Genet 2017:54:633-9.

23 Fayomi AP, Orwig KE. Spermatogonial stem cells and spermatogenesis in mice, monkeys and men. Stem Cell Res 2018;29:207-14.

24 Li MA, Alls JD, Avancini RM, Koo K, Godt D. The large Maf factor traffic jam controls gonad morphogenesis in Drosophila. Nat Cell Biol 2003;5:994-1000.

25 Zhao S, Chen D, Geng Q, Wang Z. The highly conserved LAMMER/CLK2 protein kinases prevent germ cell overproliferation in Drosophila. Dev Biol 2013;376:163-70.

26 White-Cooper H. Tissue, cell type and stage-specific ectopic gene expression and RNAi induction in the Drosophila testis. Spermatogenesis 2012;2:11-22.

27 González C, Tavosanis G, Mollinari C. Centrosomes and microtubule organisation during Drosophila development. J Cell Sci 1998;111(Pt 18:2697-706.

28 Fuller MT. Spermatogenesis. In: Bate M, Martinez-Arias A, eds. The development of Drosophila. Cold Spring Harbor Press, 1993: 71-147.

29 Wakefield JG, Bonaccorsi S, Gatti M. The Drosophila protein Asp is involved in microtubule organization during spindle formation and cytokinesis. J Cell Biol 2001;153:637-48.

30 Gao S, Giansanti MG, Buttrick GJ, Ramasubramanyan S, Auton A, Gatti M, Wakefield JG. Australin: a chromosomal passenger protein required specifically for Drosophila melanogaster male meiosis. J Cell Biol 2008;180:521-35.

31 Bucciarelli E, Giansanti MG, Bonaccorsi S, Gatti M. Spindle assembly and cytokinesis in the absence of chromosomes during Drosophila male meiosis. J Cell Biol 2003;160:993-9.

32 Williams B, Leung G, Maiato H, Wong A, Li Z, Williams EV, Kirkpatrick C, Aquadro $\mathrm{CF}$, Rieder CL, Goldberg ML. Mitch a rapidly evolving component of the $\mathrm{Ndc} 80$ kinetochore complex required for correct chromosome segregation in Drosophila. J Cell Sci 2007;120:3522-33.

33 Mengoli V, Bucciarelli E, Lattao R, Piergentili R, Gatti M, Bonaccorsi S. The analysis of mutant alleles of different strength reveals multiple functions of topoisomerase 2 in regulation of Drosophila chromosome structure. PLoS Genet 2014;10:e1004739.

34 Giansanti MG, Bonaccorsi S, Williams B, Williams EV, Santolamazza C, Goldberg ML, Gatti M. Cooperative interactions between the central spindle and the contractile ring during Drosophila cytokinesis. Genes Dev 1998;12:396-410. 
35 Giansanti MG, Farkas RM, Bonaccorsi S, Lindsley DL, Wakimoto BT, Fuller MT, Gatti M. Genetic dissection of meiotic cytokinesis in Drosophila males. Mol Biol Cell 2004;15:2509-22.

36 Practice Committee of American Society for Reproductive Medicine in collaboration with Society for Male Reproduction and Urology. Evaluation of the azoospermic male. Fertil Steril 2008;90:S74-7.

37 Robin G, Boitrelle F, Leroy X, Peers M-C, Marcelli F, Rigot J-M, Mitchell V. Bilan d'une azoospermie et évaluation histologique de la spermatogenèse. Ann Pathol 2010;30:182-95.

38 Beales PL, Elcioglu N, Woolf AS, Parker D, Flinter FA. New criteria for improved diagnosis of Bardet-Biedl syndrome: results of a population survey. J Med Genet 1999:36:437-46.

39 Forsythe E, Beales PL. Bardet-Biedl syndrome. Eur J Hum Genet 2013;21:8-13.

40 Zhang Q, Nishimura D, Vogel T, Shao J, Swiderski R, Yin T, Searby C, Carter CS, Kim G, Bugge K, Stone EM, Sheffield VC. BBS7 is required for BBSome formation and its absence in mice results in Bardet-Biedl syndrome phenotypes and selective abnormalities in membrane protein trafficking. J Cell Sci 2013;126:2372-80.

41 Davis RE, Swiderski RE, Rahmouni K, Nishimura DY, Mullins RF, Agassandian K, Philp AR, Searby CC, Andrews MP, Thompson S, Berry CJ, Thedens DR, Yang B, Weiss RM, Cassell MD, Stone EM, Sheffield VC. A knockin mouse model of the Bardet-Biedl syndrome 1 M390R mutation has cilia defects, ventriculomegaly, retinopathy, and obesity. Proc Natl Acad Sci U S A 2007;104:19422-7.

42 Fath MA, Mullins RF, Searby C, Nishimura DY, Wei J, Rahmouni K, Davis RE, Tayeh MK, Andrews M, Yang B, Sigmund CD, Stone EM, Sheffield VC. Mkks-null mice have a phenotype resembling Bardet-Biedl syndrome. Hum Mol Genet 2005;14:1109-18.

43 Mykytyn K, Mullins RF, Andrews M, Chiang AP, Swiderski RE, Yang B, Braun T, Casavant T, Stone EM, Sheffield VC. Bardet-Biedl syndrome type 4 (BBS4)-null mice implicate Bbs4 in flagella formation but not global cilia assembly. Proc Natl Acad Sci U SA 2004;101:8664-9.

44 Nishimura DY, Fath M, Mullins RF, Searby C, Andrews M, Davis R, Andorf JL, Mykytyn K, Swiderski RE, Yang B, Carmi R, Stone EM, Sheffield VC. Bbs2-null mice have neurosensory deficits, a defect in social dominance, and retinopathy associated with mislocalization of rhodopsin. Proc Natl Acad Sci U S A 2004;101:16588-93.
45 Dickinson ME, Flenniken AM, Ji X, Teboul L, Wong MD, White JK, Meehan TF, Weninger WJ, Westerberg H, Adissu H, Baker CN, Bower L, Brown JM, Caddle LB, Chiani F, Clary D, Cleak J, Daly MJ, Denegre JM, Doe B, Dolan ME, Edie SM, Fuchs H, Gailus-Durner V, Galli A, Gambadoro A, Gallegos J, Guo S, Horner NR, Hsu C-W, Johnson SJ, Kalaga S, Keith LC, Lanoue L, Lawson TN, Lek M, Mark M, Marschall S, Mason J, McElwee ML, Newbigging S, Nutter LMJ, Peterson KA, Ramirez-Solis R, Rowland DJ, Ryder E, Samocha KE, Seavitt JR, Selloum M, Szoke-Kovacs Z, Tamura M, Trainor AG, Tudose I, Wakana S, Warren J, Wendling O, West DB, Wong L, Yoshiki A, MacArthur DG, Tocchini-Valentini GP, Gao X, Flicek P, Bradley A, Skarnes WC, Justice MJ, Parkinson HE, Moore M, Wells S, Braun RE, Svenson KL, de Angelis MH, Herault $Y$, Mohun T, Mallon A-M, Henkelman RM, Brown SDM, Adams DJ, Lloyd KCK, McKerlie C, Beaudet AL, Bućan M, Murray SA, International Mouse Phenotyping Consortium, Jackson Laboratory, Infrastructure Nationale PHENOMIN, Institut Clinique de la Souris (ICS), Charles River Laboratories, MRC Harwell, Toronto Centre for Phenogenomics, Wellcome Trust Sanger Institute, RIKEN BioResource Center. High-Throughput discovery of novel developmental phenotypes. Nature 2016;537:508-14.

46 Harding SD, Armit C, Armstrong J, Brennan J, Cheng Y, Haggarty B, Houghton D, LloydMacGilp S, Pi X, Roochun Y, Sharghi M, Tindal C, McMahon AP, Gottesman B, Little MH, Georgas K, Aronow BJ, Potter SS, Brunskill EW, Southard-Smith EM, Mendelsohn C, Baldock RA, Davies JA, Davidson D. The GUDMAP database--an online resource for genitourinary research. Development 2011;138:2845-53.

47 Bonaccorsi S, Giansanti MG, Gatti M. Spindle self-organization and cytokinesis during male meiosis in asterless mutants of Drosophila melanogaster. J Cell Biol 1998; 142:751-61.

48 Williams BC, Riedy MF, Williams EV, Gatti M, Goldberg ML. The Drosophila kinesin-like protein KLP3A is a midbody component required for central spindle assembly and initiation of cytokinesis. J Cell Biol 1995;129:709-23.

49 Adams RR, Tavares AA, Salzberg A, Bellen HJ, Glover DM. pavarotti encodes a kinesin-like protein required to organize the central spindle and contractile ring for cytokinesis. Genes Dev 1998;12:1483-94.

50 Vernì F, Somma MP, Gunsalus KC, Bonaccorsi S, Belloni G, Goldberg ML, Gatti M. Feo, the Drosophila homolog of PRC1, is required for central-spindle formation and cytokinesis. Curr Biol 2004;14:1569-75. 